\title{
Education Crises as Crises for Capital
}

\author{
Glenn Rikowski ${ }^{1}$
}

Accounts of education crises typically start out from the notion that these are derivative of economic crises. Hard times for capitalist economies - with recession and consequent shortfalls in tax takes as unemployment rises - leads to cutbacks in budgets for state services, including education. The victims of these cuts are schools, colleges, universities, and students (as provision is trimmed) and staffs (redundancies, recruitment freezes and restructurings). This is The Classical Theory of Education Crisis. A critique of this perspective on education crisis is outlined in this article. Alternatively, it is argued that education crises can be crises for capital, where capitalist development in education institutions becomes threatened or terminated. Through the analysis of commodity forms, the conditions for education crises generating crises for capital are demonstrated. In this perspective, it is capital that is the victim. It is argued that when conscious attempts to go beyond existing forms of capitalist education are forged along anti-capitalist lines in alternative, oppositional educational organisations, then this poses the most threatening scenario for capital and its human representatives. [Article copies available for a fee from The Transformative Studies Institute. E-mail address: journal@transformativestudies.org Website: http://www.transformativestudies.org (02019 by The Transformative Studies Institute. All rights reserved.]

KEYWORDS: Crisis, Commodification, Education Privatisation, Labour-Power.

\section{INTRODUCTION}

There is a tendency to think of 'education crisis' in terms of statefinanced, state-run educational institutions. As the story goes, there is an

\footnotetext{
${ }^{1}$ Glenn Rikowski, Ph.D., is a Visiting Fellow in the College of Social Science, University of Lincoln, UK. Rikowski was a member of the Hillcole Group of Radical Left Educators from 1994-2002. With Anthony Green (UCL Institute of Education), Rikowski co-founded and ran the Marxism and Education: Renewing Dialogues seminars twice-yearly (May and October) from 2002-2007. He is a member of the London Branch of the Philosophy of Education Society of Great Britain (PESGB).
} 